\title{
Stimulation of Benzyladenine-Induced in vitro Shoot Organogensis from Cotyledons of Cucumis sativus L. by Proline and Abscisic Acid
}

\author{
Kalidas Shettry ${ }^{1,3}$, Geetha Shettr ${ }^{1,3}$, Hiroshi Ezura ${ }^{2}$ \\ and Katsuji OosawA ${ }^{1}$ \\ ${ }^{1}$ National Institute of Agrobiological Resources, \\ Tukuba, Ibaraki, 305, Japan. \\ ${ }^{2}$ Ibaraki Horticultural Experiment Station. \\ Minori-machi, Ibaraki, 311-32, Japan. \\ ${ }^{3}$ University of Guelph, Dept. of Crop Science, \\ Gueph, Ontario, NIG2W1, Canada.
}

(Received January 31, 1992)

(Accepted April 23, 1992)

\begin{abstract}
Addition of abscisic acid (ABA) and/or proline stimulated benzyladenine (BA)-induced multiple shoots directly from cotyledon explants $(2 \mathrm{~mm} \times 2 \mathrm{~mm}$ ) of Cucumis sativus in MS medium (Murashige and Skoog, 1962) with $3 \%$ sucrose. Stimulation of BA-induced multiple shoots by proline was statistically significant within the concentration range of $5 \mathrm{mM}-10 \mathrm{mM}$. Although at high levels of $20 \mathrm{mM}$ and $30 \mathrm{mM}$, shoots were slightly inhibited. Stimulation of multiple shoots by ABA was optimum at $50 \mu \mathrm{M}$ with higher concentrations of $200 \mu \mathrm{M}$ and $300 \mu$ $\mathrm{M}$ being very inhibitory. Addition of $50 \mu \mathrm{M}$ ABA with $10 \mathrm{mM}$ proline stimulated better quality multiple shoots and induction was observed in a maximum percentage (90\%) of the explants.
\end{abstract}

\section{Introduction}

Cucumber (Cucumis sativus L.) is an economically important vegetable crop in most regions of the world ${ }^{1}$. Studies on in vitro regeneration in this species is of considerable interest in order to improve varieties via a biotechnological approach. So far many important contributions have been made in this direction. Plant regeneration has been reported using various explants like leaf callus ${ }^{2}$, cotyledons $^{3)}$, cotyledon and embryonic axis ${ }^{4)}$, hypocotyl segments ${ }^{5)}$, petiol ${ }^{6}$, cell suspension $^{7)}$ and protoplasts $^{8}$.

In this paper we report on the stimulation of benzyladenine (BA)-induced shoot organogenesis from cotyledonary explants by the addition of proline and abscisic acid (ABA). This stimulation of organogensis through enhanced multiple shoot formation resulted in a higher number of in vitro plants being regenerated on a per seed basis.

\section{Materials and Methods}

Mature seeds of cucumber (Cucumis sativus L.) c. v.; shimosirazu (source; Yokohama Nursery, Yokohama; Japan), following uncoating and sterilization were germinated for 48 hours at $25^{\circ} \mathrm{C}$ on MS medium ${ }^{9)}$ with $2 \mathrm{mg} / l \mathrm{BA}$ and $3 \%$ sucrose, $\mathrm{pH} 5$. 8. Sterilization was done by treating seeds for 45 seconds in $70 \%$ ethanol, followed by 15 minutes treatment in $1 \%$ sodium hypochlorite and rinsed 3 times in distilled water. Following germination and cotyledon expansion for 48 hours, $2 \mathrm{~mm} \times 2$ 
$\mathrm{mm}$ cotyledon explants ${ }^{10)}$ were cut from the cotyledon area close to the cotyledonary node. From each seed four cotyledon explants were obtained (two from each half of the cotyledon). Individual explants were placed on various shoot organogenesis solid media described below. Every treatment in this study had 40 explants for each of the individual experiments with 10 explants per petridish (20 $\mathrm{m} l$ medium).

Standard MS medium with $1 \mathrm{mg} / l$ BA [Wako Pure Chemical; Osaka, Japan] and $3 \%$ sucrose, $\mathrm{pH}$ 5 . 8, originally developed for $C$. melo shoot organogensis ${ }^{10)}$ was intially tested for $C$. sativus. For $C$. sativus increasing BA to $2 \mathrm{mg} / l$ was found to be more suitable (data not shown) and therefore this concentration was used in all experiments reported in this paper. Gelrite (gellan gum; Merk; USA) at $0.2 \%$ was used as the solidifying agent. Various concentrations of proline (Nakarai Tesque, Kyoto, Japan) and ABA (Wako Pure Chemical, Oosaka, Japan) were added to the above medium and sterilized under standard autoclaving conditions.

After 25 days of culture on shoot organogenesis medium under light (16 hour cycle at an intensity of $40 \mu \mathrm{E} . \mathrm{m}^{-2} \mathrm{sec}^{-1}$ ) at $25^{\circ} \mathrm{C}$, explants were scored for the abilty to form a single shoot or multiple shoots. In many cases shoots appeared at more than one point on the explant (such explants were counted as one). No callus formation occurred on any explants in any treatments. Shoots were excised individually and transferred to $1 / 2$ strength MS medium in the absence of any growth regurator. Following root formation the plants were transferred to $1: 1$ vermiculite: sand and after proper conditioning under high relative humidity, plants were transferred to soil under green house conditions.

\section{Results and Discussion}

Organogenic response in Cucumis sativus was tested by using the method developed to induce shoot organogenesis from cotyledon explants of $C$. melo ${ }^{10}$. Our study showed (data not shown) that $2 \mathrm{mg} / \mathrm{l}$ of BA in standared MS meidum with $3 \%$ sucrose was optimum to induce shoot organogenesis in C. sativus. Under these conditions only $50 \%$ of the explants formed a mixture of single and multiple shoots and in few cases shoots formed at multiple points on the explants (Fig. 1-A). Commonly BA has been used to induce in vitro shoot organogensis in many plants species ${ }^{11,12,13)}$. Based on our initial observation in $C$. sativus on the effects of BA, we wanted to further test whether proline ${ }^{14)}$ and $\mathrm{ABA}^{15)}$ could stimulate $\mathrm{BA}$-induced shoot organogenesis.

Under the influence of proline, a significant percentage of the shoots induced were multiple in nature (Fig. 1-B). This also resulted in higher numbers (6.8-8.5) of plants being regenerated on a per seed basis (Table 1). Statistically there was a significant difference between the control and any of the proline treatments. But there was no significant difference in the number of plants regenerated among various proline treatments. At higher concentrations of proline (20 mM and $30 \mathrm{mM})$, shoots were slightly inhibited. The increase in the extent of BA-induced multipleshoot formation following the addition of proline $(5 \mathrm{mM}-30 \mathrm{mM})$ is interesting. Previously it was reported that proline increased embryogenesis in some plant species ${ }^{14,16)}$ and recently in our laboratory proline stimulated BA-induced shoot organogenesis in Lagenaria siceraria and C. melo (unpublished results). The mechanism of these proline-stimulated plant regeneration must be investigated in detail.

ABA concentration of $50 \mu \mathrm{M}$ and $100 \mu \mathrm{M}$ not only stimulated BA-induced multiple shoot formation in $90 \%$ of the explants (Fig. 1-C; Table 2), but also very few single shoots were formed. In many explants, shoots were formed at multiple points on the explants. The efficiency of stimulation of shoot formation decreased at $200 \mu \mathrm{M}$ and $300 \mu \mathrm{M}$ ABA levels and explants showed severe signs 


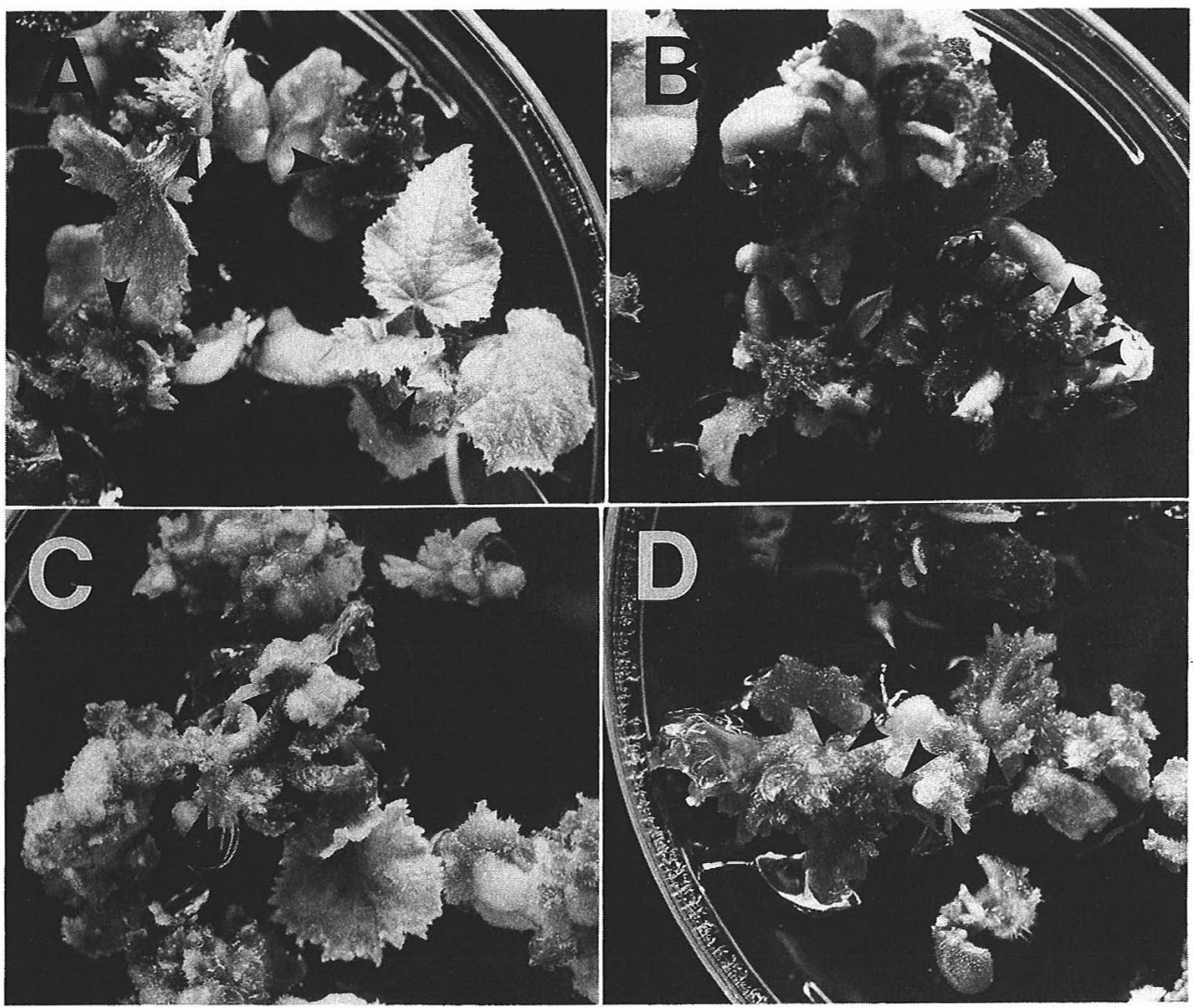

Fig. 1 Shoot formation from cotyledonary explants of Cucumis sativus L. A) on standard MS medium supplemented with $2 \mathrm{mg} / l$ benzyladenine and $3 \%$ sucrose and stimulated multiple shoot formation by B) $10 \mathrm{mM}$ proline, C) $50 \mu \mathrm{M}$ abscisic acid and D) $10 \mathrm{mM}$ proline and $50 \mu \mathrm{M}$ absicsic acid. Arrowheads indicate shoot apex.

Table 1. Effect of proline on benzyladenine-induced shoot formation* of Cucumis sativus L.

\begin{tabular}{cccc}
\hline $\begin{array}{c}\text { Proline** } \\
(\mathrm{mM})\end{array}$ & $\begin{array}{c}\text { Frequency of } \\
\text { single shoot } \\
\text { formation (\%) }\end{array}$ & $\begin{array}{c}\text { Frequency of } \\
\text { multiple shoot } \\
\text { formation }(\%)\end{array}$ & $\begin{array}{c}\text { Average number of } \\
\text { regenerated plants } \\
\text { per seed }\end{array}$ \\
\hline 0 & 22.5 & 17.5 & $3.0 \mathrm{a}^{* * *}$ \\
5 & 15.0 & 30.0 & $8.3 \mathrm{~b}$ \\
10 & 5.0 & 35.0 & $8.5 \mathrm{~b}$ \\
20 & 7.5 & 22.5 & $7.0 \mathrm{~b}$ \\
30 & 5.0 & 20.0 & $6.6 \mathrm{~b}$ \\
\hline
\end{tabular}

* The results are an average of two independent experiments.

** The basal medium was standard MS medium supplemented with $2 \mathrm{mg} / \mathrm{l}$ benzyladenine and $3 \%$ sucrose. There were 40 explants per treatment which corresponds to 10 seeds.

*** In this column numbers followed by same letter are not significantly different from each other at $5 \%$ level of confidence using Duncan's multiple range test.

of inhibition (data not shown). As many as 24 and 19 plants were regenerated on a per seed basis at $50 \mu \mathrm{M}$ and $100 \mu \mathrm{M}$ ABA levels respectively (Table 2). Addition of ABA at concentrations of $50 \mu \mathrm{M}$ and $100 \mu \mathrm{M}$ with $10 \mathrm{mM}$ proline enhanced the quality of multiple shoots (Fig.1-D). The shoots were green and also the treatment resulted in higher number of plants being regenerated on a per 
Table 2. Effect of proline $(10 \mathrm{mM})$ and varying levels of abscisic acid on benzyladenine-induced shoot formation* of Cucumis sativus $\mathrm{L}$.

\begin{tabular}{lccc}
\hline $\begin{array}{c}\text { ABA }\left(\mu \mathrm{M}^{* *}\right) \\
\text { levels with } \\
\text { and without } \\
10 \text { mM proline }\end{array}$ & $\begin{array}{c}\text { Frequency of } \\
\text { single shoot } \\
\text { formation } \\
(\%)\end{array}$ & $\begin{array}{c}\text { Frequencey of } \\
\text { multiple shoot } \\
\text { formation } \\
(\%)\end{array}$ & $\begin{array}{c}\text { Average number of } \\
\text { regenerated plant } \\
\text { per seed }\end{array}$ \\
\hline None & 22.5 & 22.5 & $3.1 \mathrm{a}^{* * *}$ \\
Proline & 12.5 & 30.0 & $8.8 \mathrm{~b}$ \\
ABA 50 & 5.0 & 85.0 & $24.2 \mathrm{~b}$ \\
ABA 50+Proline & 5.0 & 90.0 & $30.8 \mathrm{e}$ \\
ABA 100 & 2.5 & 70.0 & $18.8 \mathrm{c}$ \\
ABA 100+Proline & 2.5 & 87.5 & $24.0 \mathrm{~d}$ \\
ABA 200 & 2.5 & 47.5 & $12.1 \mathrm{~b}$ \\
ABA 200+Proline & 0.0 & 70.0 & $14.4 \mathrm{~b}, \mathrm{c}$ \\
ABA 300 & 0.0 & 15.0 & $4.2 \mathrm{a}$ \\
ABA 300+Proline & 0.0 & 30.0 & $5.4 \mathrm{a}$
\end{tabular}

* The results are an average of two independent experiments.

** The basal medium was standard MS medium supplemented with $2 \mathrm{mg} / \mathrm{l}$ benzyladenine and $3 \%$ sucrose. There were 40 explants per treatment which corresponds to 10 seeds.

*** In this column, numbers followed by same letter are not significantly different at $5 \%$ level of confidence using Duncan's multiple range test.

seed basis. Concentrations of $50 \mu \mathrm{M}$ and $100 \mu \mathrm{M}$ ABA with $10 \mathrm{mM}$ proline resulted on an average of 31 and 24 plants being regenerated per seed, respectively (Table 2 ). In all the cases the shoots were excised individually and rooted on $1 / 2$ strength hormone free MS medium, before being conditioned to adult plants (Fig. 2). The mechanism through which ABA brings about stimulation of BA-induced shoot organogenesis is not known. This fundamental questions will be very interesting to probe in detail.

On the applied side, proline and ABA stimulation of BA-induced shoot organogenesis through enhancement of multiple shoot formation provides; a) Enhanced efficiency of in vitro plant regeneration in cucumber using cotyledon explants. b) Cotyledon explants could be treated with mutagens and potentially various stress and pathogen tolerent plants could be selected. c) Cotyledon explants could be used to transfer useful genes via Agrobacterium or particle gun bombardment and transgenic plants

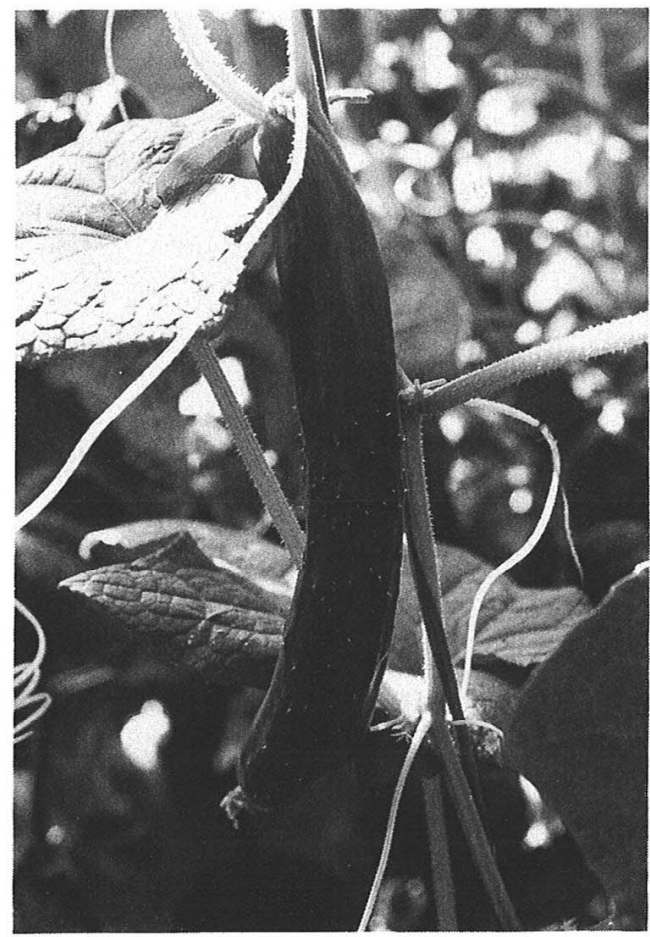

Fig. 2 Fertile adult cucumber plant obtained from in vitro procedure. can be regenerated via shoot organogenesis.

Acknowledgement; K. S. was supported by the Japan government's Science and Technology Agency post-doctoral fellowship while undertaking this work. 


\section{References}

1) Malepszy, S., 1988. In "Biotechnology in Agriculture and Foresty, Vol. 6 Crops II" (ed. by Bajaj, Y. P. S.), p. 277-293. Springer-Verlag, Berlin-Heidelberg.

2) Melepszy, S. A. Nadolska-Orczyk, 1983. Z. Pflanzenphysiol., 111: 273-276.

3) Kim, S. G., J. R. Chang, H. C. Cha, K. W. Lee, 1988. Plant Cell Tissue Organ Culture, 12: 67-74.

4) Msikita, W., R. M. Skirivin, J. A. Juvik, W. E. Splittstoesser, N. Ali, 1990. Hort. Sci., 25: 474-477.

5) Rajasekaran, K., M. G. Mullins, Y. Nair, 1983. Ann. Bot., 52: 417-420.

6) Wehner, T. C., R. D. Locy, 1981. Hort. Sci., 16: 759-760.

7) Chee, P. P., D. M. Tricoli, 1988. Plant Cell Rep., 7: 274-277.

8) Punja, Z. K., F. A. Tang, G. G. Sarmento, 1990. Plant Cell Rep., 9: 61-64.

9) Murashige, T., F. Skoog, 1962. Physiol. Plant., 15: 473-497.

10) Dirks, R., M. S. Van Buggenum, 1989. Plant Cell Rep. 7: 626-627.

11) Patel, K. R., T. A. Thorpe, 1982. Bot. Gaz. (Chicago), 145: 312-317.

12) Tanimoto, S., Harada, 1982. Biochem. Physiol. Pflanzen., 177: 222-228.

13) Sharma, K. K., S. S. Bhojwani, T. A. Thorpe, 1990. Plant Science, 66: 247-253.

14) Armstrong, C. L., C. E. Green., 1985. Planta, 164: 207-214.

15) Ammirato, P. V., 1986. In "Plant Tissue Culture and its Agricultural Application" (ed. by Wither, L. A., P. G. Alderson), p. 23-45 Butterworths Inc., London.

16) Trigiano, R. M., B. V. Conger, 1987. J. Plant Physiol., 130: 49-55.

\section{《和文要約》}

プロリンとアブシジン酸添加によるキュウリ子葉からの多芽体誘導と植物体再生率の向上

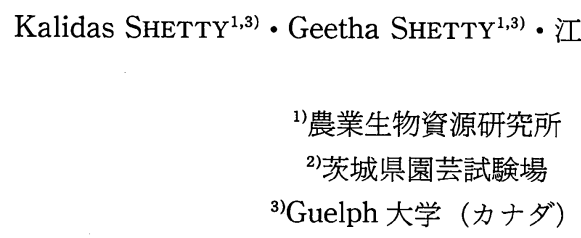

キュウリ (Cucumis sativus) 子葉片 $(2 \mathrm{~mm} \times 2 \mathrm{~mm})$ からのベンジルアデニンによる多芽体誘導と植物 体再生における，MS 培地へのプロリンとアブシジン酸の添加の効果を検討した．まず，プロリン単独添加 では, $10 \mathrm{mM}$ で切片からの多芽体誘導頻度と種子あたりの再生植物体数が最高となり，それぞれ無添加区 の 2.0 倍, 2.8 倍に向上した。 またアブシジン酸単独添加では, $50 \mu \mathrm{M}$ で多芽体誘導頻度と植物再生数が最 高となり，それぞれ無添加区の 3.8 倍，7.8 倍に向上した。さらに両者を同時に添加した場合では，多芽体 誘導の頻度は, 無添加区の 4.0 倍にあたる $90 \%$ に，1 種子からの植物体再生数は 9.9 倍にあたる 30.8 本と なり，著しい効果が認められた．今回の実験で明らかにしたキュウリの不定芽誘導と植物体再生率の向上に よってキュウリの培養系は従来に増して幅広い利用が可能になると考えられる. 